\title{
Heat Content, Free-energy Function, Entropy, and Heat Capacity of Ethylene, Propylene, and the Four Butenes to $1,500^{\circ} \mathrm{K}^{\prime}$
}

\author{
By John E. Kilpatrick ${ }^{2}$ and Kenneth S. Pitzer ${ }^{3}$
}

\begin{abstract}
Values are presented for the following thermodynamic properties for ethylene, propylene and the four butenes, in the iheal gaseous state, to $1,500^{\circ} \mathrm{K}$ : heat-content function, $\left(H^{\circ}-H_{0}^{\circ}\right) / T$; free-energy function, $\left(F^{\circ}-H_{0}^{\circ}\right) / T$; entropy, $S^{\circ}$; heat content, $\left(H^{\circ}-H_{0}^{\circ}\right)$; heat capacity, $C_{\boldsymbol{p}}^{\circ}$.
\end{abstract}

\section{Introduction}

As part of the work of the American Petroleum Institute Research Project 44, this report presents the results of the calculations of the thermodynamic properties of the heat-content function, free-energy function, entropy, heat content, and heat capacity, in the ideal gaseous state, to $1,500^{\circ} \mathrm{K}$, for ethylene, propylene, 1-butene, cis2-butene, trans-2-butene, and isobutene. The calculations are based in large part on vibrational frequencies given in a pending report [4]. ${ }^{4}$

\footnotetext{
1 This investigation was performed as part of the work of the American Petroleum Institute Research Project 44 on the "Collection, Analysis, and Calculation of Data on the Properties of Hydrocarbons."

2 Research Associate on the American Petroleum Institute Research Project 44 at the National Bureau of Standards.

${ }^{3}$ Associate Supervisor of the American Petroleum Institute Research Project 44; Professor of Chemistry at the University of California, Berkeley, Calif.

4 Figures in brackets indicate literature references at the end of this paper.
}

\section{Contents}

II. Unit of energy and constants_._.

III. Method of calculation _._. 164
IV. Data used in the calculations for ethylene, Propylene, cis-2-butene, trans-2-butene, and

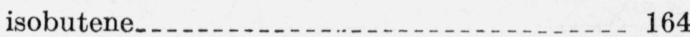

1. Moments of inertia _........... 164

(a) Ethylene .......... 164

(b) Propylene .............. 164

(c) cis-2-Butene............. 164

(d) trans-2-Butene........... 165

(e) Isobutene _......... 165

2. Vibrational frequencies........... _. 165

(a) Ethylene .......... 165

(b) Propylene....... 165

(c) cis-2-Butene........ 165

(d) trans-2-Butene_._._._. 166

(e) Isobutene............. 166

3. Potential barriers restricting internal rotation_........ 166

(a) Propylene . . .

(b) cis-2-Butene............ 166

(c) trans-2-Butene............ 166

(d) Isobutene_........ 167

V. Data used in the calculations for 1-butene_.... 167

1. Vibrational frequencies and moments of inertia...... 167

2. Internal (skeletal) rotation _....... 167

VI. Results_..._._. 169

VII. References_... 171 


\section{Unit of Energy and Constants}

The unit of energy used in this report is the conventional thermochemical calorie, defined as follows:

1 calorie $=4.1833$ international joules.

The values of the physical constants used in the calculations are from the " $\alpha$ " tables of the
American Petroleum Institute Research Project 44 , which values have been given in an earlier report from this laboratory $[1,23]$. The equations for the thermodynamic contributions for translation and rotation are from the same source [23] and are also reported in reference [1].

The terms for restricted internal rotation were computed from the tables of Pitzer and Gwinn [2].

\section{Method of Calculation}

If the complete set of energy levels (quantum states) are known for a given molecule, the values of the thermodynamic functions may be computed exactly. Except for the simpler molecules, the knowledge of the energy levels is not complete enough to permit exact calculation, and certain simplifying assumptions must be introduced regarding the relations among the several kinds of energy levels, as follows: (1) The various vibrations are harmonic; (2) the moment of inertia is not a function of the rotational quantum state; (3) no coupling exists between the vibrational and rotational states of energy; (4) if restricted internal rotation occurs, the restriction is from a cosine type barrier and no potential coupling exists between different internal rotations.

The foregoing assumptions, which are customarily made in such work and which have been made in the present calculations, introduce errors that are smaller than the uncertainties of the presently available experimental data.

\section{Data Used in the Calculation for Ethylene, Propylene, cis-2-Butene, trans-2-Butene, and Isobutene}

\section{Moments of inertia}

(a) Ethylene

Gallaway and Barker [3] have measured the moments of inertia of ethylene accurately from the rotational structure of several infrared bands. Their results have been adopted for the present calculations.

The three moments of inertia are $0.5750 \times 10^{-39}$, $2.809 \times 10^{-39}$, and $3.384 \times 10^{-39} \mathrm{~g} \mathrm{~cm}^{2}$. These moments of inertia are consistent with the following dimensions: Length of $\mathrm{C}=\mathrm{C}$ bond, $1.353 \mathrm{~A}$; length of $\mathrm{C}-\mathrm{H}$ bond, $1.071 \mathrm{~A} ; \mathrm{H}-\mathrm{C}-\mathrm{H}$ angle, $120^{\circ}$. The symmetry number, $\sigma$, of ethylene is four. See reference [4].

The entropy of translation and rotation for ethylene gas in the ideal state is then

$$
S^{\circ}{ }_{t+r}=6.524+18.3026 \log _{10} T \mathrm{cal} / \mathrm{deg} \text { mole. }
$$

\section{(b) Propylene}

The moments of inertia of propylene and of the butenes were calculated assuming that (1) the
$\mathrm{C}=\mathrm{C}$ and $\mathrm{C}=\mathrm{H}$ bonds are the same length as in ethylene; (2) the four bonds attached to the $\mathrm{C}=\mathrm{C}$ group are inclined at the same angles as in ethylene, namely $120^{\circ}$; (3) the single bond $\mathrm{C}-\mathrm{C}$ length is 1.54 angstroms; (4) the angles in each methyl group are tetrahedral; (5) the $\mathrm{C}-\mathrm{H}$ bond length in a methyl group is 1.09 angstroms.

The three principal moments of inertia of propylene are $1.9348 \times 10^{-39}, 8.9199 \times 10^{-39}$, and $10.3286 \times 10^{-39} \mathrm{~g} \mathrm{~cm}^{2}$. The axis of the smallest moment makes an angle of $33^{\circ} 40^{\prime}$ with the $\mathrm{C}=\mathrm{C}$ bond. The reduced moment for internal rotation is $4.073 \times 10^{-40} \mathrm{~g} \mathrm{~cm}^{2}$. The total symmetry number is three. This number arises wholly from the symmetry of the internal rotation.

The entropy of translation, over-all rotation, and free internal rotation for propylene gas in the ideal state is

$$
S^{\circ}{ }_{t+r+f_{r}}=11.621+20.5904 \log _{10} T \mathrm{cal} / \mathrm{deg} \text { mole. }
$$

\section{(c) cis-2-Butene}

The three principal moments of inertia are $5.9977 \times 10^{-39}, 14.2431 \times 10^{-39}$, and $19.1886 \times 10^{-39}$, 
in $\mathrm{g} \mathrm{cm}^{2}$. The reduced moments of the two methyl groups have the same value, $5.037 \times 10^{-40}$ $\mathrm{g} \mathrm{cm}^{2}$. The total symmetry number is 18 which is composed of factors of three for each internal rotation and two for over-all rotation.

The entropy of translation, over-all rotation and free internal rotation for cis-2-butene in the ideal gaseous state is

$S_{t+r+f r}^{\circ}=11.400+22.8783 \log _{10} T$ cal/deg mole.

\section{(d) trans-2-Butene}

The three principal moments of inertia are $2.5675 \times 10^{-39}, 22.440 \times 10^{-39}$, and $23.9556 \times 10^{-39}$, in $\mathrm{g} \mathrm{cm}^{2}$. The axis of the smallest moment makes an angle of $39^{\circ} 58^{\prime}$ with the $\mathrm{C}=\mathrm{C}^{\prime}$ bond. The reduced moment of each of the methyl groups is $4.208 \times 10^{-40} \mathrm{~g} \mathrm{~cm}^{2}$. The total symmetry number is 18 , subdivided as in cis-2-butene.

The entropy of translation, over-all rotation and free internal rotation for trans-2-butene in the gaseous state is

$S_{t+r+f r}^{\circ}=10.871+22.8783 \log _{10} T \mathrm{cal} / \mathrm{deg}$ mole.

\section{(e) Isobutene (2-methylpropene)}

The three principal moments of inertia are $8.9842 \times 10^{-39}, 10.7646 \times 10^{-39}$, and $18.6968 \times 10^{-39}$, in $\mathrm{g} \mathrm{cm}^{2}$. The reduced moment of each of the two methyl groups is $4.999 \times 10^{-40} \mathrm{~g} \mathrm{~cm}^{2}$. The total symmetry number is 18 , subdivided as in cis-2butene.

The entropy of translation, over-all rotation, and free internal rotation, for isobutene gas in the ideal gaseous state is:

$S_{t+r+f r}^{\circ}=11.482+22.8783 \log _{10} T \mathrm{cal} / \mathrm{deg}$ mole.

\section{Vibrational frequencies}

\section{(a) Ethylene}

The vibrational assignment of Gallaway and Barker [3] has been adopted. The 12 vibrations are divided into 7 symmetry types. The frequencies of these vibrations, in wave numbers and classified according to symmetry, are listed in the following tabulation:

$$
\begin{aligned}
& \text { Symmetry: point group } V_{\mathrm{h}} \\
& \mathrm{A}_{\mathbf{1} \mathbf{g}} \begin{cases}3019.3 \\
1623.3\end{cases} \\
& \mathrm{B}_{3 \mathrm{u}}\left\{\begin{array}{l}
3105.5 \\
995.0 \\
1342.4
\end{array}\right. \\
& \mathrm{B}_{1 \mathrm{~g}}\left\{\begin{array}{lll}
2989.4 & \mathrm{~A}_{1 \mathrm{u}} & 825 \\
1443.9 & \mathrm{~B}_{2 \mathrm{~g}} & 943 \\
3069 & \mathrm{~B}_{1 \mathrm{u}} & 949.2 \\
1055 & &
\end{array}\right.
\end{aligned}
$$

\section{(b) Propylene}

The only symmetry element of the propylene molecule is the plane of the skeletal frame, $\mathrm{C}=\mathrm{C}-\mathrm{C}$. The 20 vibrations can therefore be divided into only two classes.

The argument for the following assignment is given in a preceding report [4]. The description of the motion involved is only approximate. The

\begin{tabular}{|c|c|c|}
\hline \multicolumn{3}{|c|}{ Symmetry: point group $\mathrm{C}_{\mathrm{s}}$} \\
\hline $\mathrm{A}^{\prime}$ & $\mathrm{A}^{\prime \prime}$ & \\
\hline $3050(3)$ & $\ldots$ & $\mathrm{C}-\mathrm{H}$ stretching (ethylenic) \\
\hline $2950(2)$ & 2950 & $\mathrm{C}-\mathrm{H}$ stretching (methyl) \\
\hline 1649 & - - - & $\mathrm{C}=\mathrm{C}$ stretching \\
\hline 1444 & 1444 & $\mathrm{CH}_{3} \quad \delta(\pi)$ \\
\hline 1415 & $\ldots$ & $\mathrm{CH}_{2}$ \\
\hline 1370 & $-\ldots$ & $\mathrm{CH}_{3}$ \\
\hline 1297 & 990 & wagging \\
\hline - - - - - & 580 & $\mathrm{C}=\mathrm{C}$ twisting \\
\hline 1042 & 1050 & $\mathrm{CH}_{3}$ wagging \\
\hline 1172 & 911 & $\mathrm{CH}_{2}$ wagging \\
\hline 930 & $\ldots$ & $\mathrm{C}-\mathrm{C}$ stretching \\
\hline 417 & $\ldots$ & Skeletal bending \\
\hline
\end{tabular}
frequencies are given in wave numbers, $\mathrm{cm}^{-1}$ :

(c) cis-2-Butene

The symmetry of cis-2-butene allows its 28 vibrations to be classified into four symmetry types. A discussion of the following assignment may be found in another report [4]. The frequencies are

\begin{tabular}{|c|c|c|c|}
\hline $\mathrm{A}_{1}$ & $\mathrm{~A}_{2}$ & $\mathrm{~B}_{1}$ & $\mathrm{~B}_{2}$ \\
\hline 3050 & $\ldots$ & $\ldots$ & 3050 \\
\hline $2950(2)$ & 2950 & 2950 & $2950(2)$ \\
\hline 1672 & -..- & - - - & -... \\
\hline 876 & -..- & -..- & 986 \\
\hline 1450 & 1450 & 1450 & 1450 \\
\hline 1380 & -..- & - . - & 1380 \\
\hline 1267 & -... & - - - & 1390 \\
\hline -... & 1050 & 673 & -... \\
\hline 1018 & -..- & - - - & 1064 \\
\hline & 950 & 1040 & -1 \\
\hline 304 & -... & -... & 581 \\
\hline -... & 402 & - - & -... \\
\hline
\end{tabular}
given in wave numbers, $\mathrm{cm}^{-1}$ :

$\mathrm{C}-\mathrm{H}$ stretching (ethylenic)
$\mathrm{C}-\mathrm{H}$ stretching (methyl)
$\mathrm{C}=\mathrm{C}$ stretching
$\mathrm{C}-\mathrm{C}$ stretching
$\mathrm{CH}_{3} \delta(\tau)$
$\mathrm{CH}_{3} \delta(\sigma)$
$\mathrm{C}-\mathrm{H}$ wagging, planar
$\mathrm{C}-\mathrm{H}$ wagging, non planar
$\mathrm{CH}_{3}$ wagging, planar
$\mathrm{CH}_{3}$ wagging, nonplanar
$\mathrm{Skeletal}$ bending
$\mathrm{C}=\mathrm{C}$ twisting




\section{(d) trans-2-Butene}

Although this isomer has the symmetry $\mathrm{C}_{2 \mathrm{~h}}$ instead of the $\mathrm{C}_{2 \mathrm{v}}$ of cis-2-butene, the two point

\begin{tabular}{|c|c|c|c|c|}
\hline \multicolumn{5}{|c|}{ Symmetry: point group $\mathrm{C}_{2 \mathrm{~b}}$} \\
\hline$A_{\mathbf{g}}$ & $A_{u}$ & $\mathrm{~B}_{\mathrm{g}}$ & $\mathrm{B}_{\mathrm{u}}$ & \\
\hline 3050 & -..- & $\ldots$ & 3050 & $\mathrm{C}-\mathrm{H}$ stretching (ethylenic) \\
\hline $2950(2)$ & 2950 & 2950 & $2950(2)$ & $\mathrm{C}-\mathrm{H}$ stretching (methyl) \\
\hline 1681 & $\ldots$ & -..- & $\ldots$ & $\mathrm{C}=\mathrm{C}$ stretching \\
\hline 870 & -..- & -..- & 1065 & $\mathrm{C}-\mathrm{C}$ stretching \\
\hline 1450 & 1450 & 1450 & 1450 & $\mathrm{CH}_{3} \delta(\pi)$ \\
\hline 1389 & ...- & ...- & 1375 & $\mathrm{CH}_{3} \delta(\sigma)$ \\
\hline 1309 & .... & ...- & 1304 & $\mathrm{C}-\mathrm{H}$ wagging, planar \\
\hline & 964 & 746 & -..- & $\mathrm{C}-\mathrm{H}$ wagging, nonplanar \\
\hline 1080 & -..- & -..- & 973 & $\mathrm{CH}_{3}$ wagging, planar \\
\hline$\ldots$ & 1030 & 1043 & -..- & $\mathrm{CH}_{3}$ wagging, nonplanar \\
\hline 507 & $-\ldots$ & -..- & 290 & skeletal bending \\
\hline- & 240 & .... & -... & $\mathrm{C}=\mathrm{C}$ twisting \\
\hline
\end{tabular}

\section{(e) Isobutene}

Isobutene has the same symmetry as cis-2butene, $\mathrm{C}_{2 \mathrm{v}}$, but the presence of both methyl necessary [4]: groups are isomorphic and the classifications of the frequencies are quite similar [4]:

groups on the same end of the $\mathrm{C}=\mathrm{C}$ frame makes a slightly different description of the vibrations

\begin{tabular}{|c|c|c|c|c|}
\hline & Symmet & ooint $g$ & $\mathrm{C}_{2 \mathrm{v}}$ & \\
\hline$A_{1}$ & $\mathrm{~A}_{2}$ & $\mathrm{~B}_{1}$ & $\mathrm{~B}_{2}$ & \\
\hline 3050 & & -..- & 3050 & $\mathrm{C}-\mathrm{H}$ stretching (ethylenic) \\
\hline $2950(2)$ & 2950 & 2950 & $2950(2)$ & $\mathrm{C}-\mathrm{H}$ stretching (methyl) \\
\hline 1664 & $-\ldots$ & -... & -..- & $\mathrm{C}=\mathrm{C}$ stretching \\
\hline 800 & -..- & -..- & 986 & $\mathrm{C}-\mathrm{C}$ stretching \\
\hline 1450 & 1450 & 1450 & 1450 & $\mathrm{CH}_{3} \delta(\pi)$ \\
\hline 1380 &.-- & $\ldots$ & 1380 & $\mathrm{CH}_{3} \delta(\sigma)$ \\
\hline 1390 & -..- & ...- & ...... & $\mathrm{CH}_{2}$ \\
\hline-- & -..- & -... & 1280 & $\mathrm{CH}_{2}$ wagging, planar \\
\hline -..- & $-\ldots$ & 888 & -....- & $\mathrm{CH}_{2}$ wagging, nonplanar \\
\hline 1053 & -..- & ...- & 1007 & $\mathrm{CH}_{3}$ wagging, planar \\
\hline -..- & 988 & 1066 & -..- & $\mathrm{CH}_{3}$ wagging, nonplanar \\
\hline 378 & $\ldots$ & 391 & 431 & Skeletal bending \\
\hline ...- & 700 & -... & ...- & $\mathrm{C}=\mathrm{C}$ twisting \\
\hline
\end{tabular}

\section{Potential barriers restricting internal rotation}

\section{(a) Propylene}

A threefold cosine type barrier of $1,950 \mathrm{cal} / \mathrm{mole}$, when combined with the previously mentioned constants, was found to give results agreeing satisfactorily with the experimental values of the entropy [5] and the gaseous heat capacity [6].

\section{(b) cis-2-Butene}

A threefold restricting potential of $450 \mathrm{cal} / \mathrm{mole}$ for each methyl group was found to give satisfactory agreement with the experimental values of the entropy [7] and the gaseous heat capacity [8].

This abnormally low value probably arises from the opposing effects of the normal methyl barriers and steric hindrance between the two methyl groups.

The assumption of independent cosine type barriers is probably poorer in cis-2-butene than in the other members of this family. The symmetry of the internal rotations prohibits exactly this type of barrier. However, the effective height of the barrier for any reasonable shape is so low that the details of the shape have relatively little effect upon the thermodynamic functions.

\section{(c) trans-2-Butene}

The potential barrier giving the best agreement with the experimental values of the entropy [9] and the gaseous heat capacity [8] was found to be $1,950 \mathrm{cal} / \mathrm{mole}$.

This value agrees, as it should, with that of propylene. There is probably little or no potential coupling between the two methyl groups to increase the apparent height of the barrier.

Additional confirmation for this value is given 
by the $210 \mathrm{~cm}^{-1}$ Raman line of trans-2-butene. By several methods a barrier height of about 2,000 cal/mole can be calculated if this line is assigned to $\mathrm{B}_{\mathrm{g}}$ internal rotation.

\section{(d) Isobutene}

In this case a value of $2,350 \mathrm{cal} / \mathrm{mole}$ gives the best agreement with the experimental values of the entropy [10] and the gaseous heat capacity [11].
This apparent increase from the value 1,950 $\mathrm{cal} / \mathrm{mole}$ found for propylene and trans-2-butene is undoubtedly due to the neglected potential coupling terms between the two methyl rotations. The phenomenon is similar to the apparent barrier increase in the series ethane, propane, isobutane and neopentane. Preliminary calculations upon the thermodynamic effect of such coupling indicate that this explanation is valid.

\section{Data Used in the Calculations for 1-butene}

\section{Vibrational frequencies and moments of inertia}

On the basis of the information and data available at the present time, it does not seem feasible to make a satisfactory vibrational assignment in detail for 1-butene. The symmetry of the molecule is so low that a normal coordinate analysis of its vibrations would be very difficult. The situation is further complicated by the unsymmetrical rotation in the skeleton of the molecule. In the light of these difficulties it was decided to use a semiempirical approach to the calculation of the thermodynamic functions for 1-butene.

The thermodynamic effect of the vibrations was taken to be the same as that of the 20 frequencies of propylene, the 6 characteristic frequencies of the methylene group [12], $1 \mathrm{C}-\mathrm{C}$ stretching frequency of $995 \mathrm{~cm}^{-1}$, and 1 skeletal bending frequency of $320 \mathrm{~cm}^{-1}$. This last frequency was taken from the Raman spectrum [13], and its assignment, although somewhat doubtful, appears justified because 1-butene should possess a skeletal bending mode of vibration of about this magnitude, on the basis of analogous molecular structures.

The moments of inertia were calculated from the dimensions used for propylene, with the axis of the methyl group lying $60^{\circ}$ out of the plane of the extended or trans configuration of the carbon skeleton. The reason for this choice is discussed later. The product of the three principal moments of inertia is calculated to be $2,232 \times 10^{-117} \mathrm{~g}^{3} \mathrm{~cm}^{6}$.

The potential barrier restricting the rotation of the methyl group was taken to be $3,400 \mathrm{cal} / \mathrm{mole}$, as in propane.

\section{Internal (Skeletal) Rotation}

The only remaining factor to be considered is the skeletal rotation. The use of Fisher-Hirsch- felder molecular models proved quite helpful in this regard. If it were not for the steric interference of the methyl and the ethylenic groups, there would probably be three equivalent minima at $60^{\circ}, 180^{\circ}$, and $300^{\circ}$, counting from the extended, planar configuration The two groups apparently interfere enough to raise the minimum at $180^{\circ}$ by several thousand calories. The unperturbed barrier would be expected to be about the same height as in propylene or trans-2-butene. This steric interference would then have the effect of making the rotational potential energy almost constant from $120^{\circ}$ to $240^{\circ}$ in the angle of rotation. There undoubtedly is not complete cancellation of this minimum. The large number of Raman lines indicates more than one kind of skeletal minimum. However, for thermodynamic purposes, the details of the barrier in this region are relatively unimportant.

The following potential satisfies the above requirements:

$$
\begin{array}{lr}
V=(1 / 2) V_{0}(1-\sin 3 \phi),-120^{\circ}<\phi<120^{\circ} \\
V=V_{0}, & 120^{\circ}<\phi<240^{\circ}
\end{array}
$$

The classical form of the partition function is a satisfactory approximation to the exact partition function when, as is true in this molecule, the reduced moment of inertia for the rotation is several times the moment of inertia of a methyl group.

When these calculations were made, an exact formula for the proper reduced moment of inertia for the skeletal rotation was not available, and an estimated value of $20 \times 10^{-40} \mathrm{~g} \mathrm{~cm}^{2}$ was used. Since then, the theory has been developed further [21], but the minor changes required seemed unjustified in view of the approximate character of other parts of the calculations for 1-butene. This matter is discussed further below. 
The rotational partition function is given by the expression

$$
Q=Q_{f}\left(\frac{1}{2 \pi}\right) \int_{0}^{2 \pi} e^{-V / R T} d \phi,
$$

where $Q_{f}$ is the usual partition function for free rotation, $\mathrm{V}$ the potential barrier as a function of $\phi, R$ the gas constant, and $T$ the absolute temperature.

When eq 7 and 8 are combined, the following relations may be derived:

$$
\begin{gathered}
Q / Q_{f}=e^{-x}\left(\frac{2}{3} I_{0}(x)+\frac{1}{3} e^{-x}\right) \\
\left(F_{f}-F^{\prime}\right) / R T=-x+\ln \left(\frac{2}{3} I_{0}(x)+\frac{1}{3} e^{-x}\right) \\
H_{r} / R T=(1 / 2)+x-\frac{x\left(2 I_{1}(x)-e^{-x}\right)}{2 I_{0}(x)+e^{-x}} \\
C_{r} / R=(1 / 2)+x^{2}-\frac{2 x I_{1}(x)}{2 I_{0}(x)+e^{-x}} \\
-x^{2}\left(\frac{2 I_{1}(x)-e^{-x}}{2 I_{0}(x)+e^{-x}}\right)^{2} .
\end{gathered}
$$

In eq 9 to $12, x=V_{o} / 2 R T, I_{n}(x)=i^{-n} J_{n}(i x)$. $J_{n}(y)$ is the ordinary Bessel function of the first kind. $I_{n}(x)$ is real when $x$ is real. $\left(F_{f}-F\right) / T$, $H_{r} / T$, and $C_{r}$ are the differences in the free-energy function for free and restricted rotation, the heatcontent function and the heat capacity for restricted rotation, respectively. In the last two cases (eq 11 and 12), the term $1 / 2$ is the limit of $H_{r} / R T$ and $C_{r} / R$ as $x$ (and $V_{o}$ ) approach zero. It is therefore the usual heat-content function and heat-capacity contribution for free rotation.

It was found that the best agreement with the experimental equilibrium data on the isomerization of the $n$-butenes $[14,15,16]$ could be obtained with $V_{0}=2,400 \mathrm{cal} / \mathrm{mole}$. This comparison is presented in reference [17]. This value is reasonable in magnitude on physical grounds and in addition gives good agreement with the abovementioned experimental equilibrium data over a wide temperature range.
The value for the entropy of 1-butene in the ideal gaseous state at $266.91^{\circ} \mathrm{K}$ obtained by application of the third law to appropriate calorimetric data is $70.87 \pm 0.20 \mathrm{cal} / \mathrm{deg}$ mole [18]. The present calculations yield $71.19 \mathrm{cal} / \mathrm{deg}$ mole for the same temperature. A slightly higher barrier to internal rotation would lower the calculated value of the entropy, but would make less good the agreement with the equilibrium data. In view of the possibility of some end-for-end randomness of position of 1-butene molecules in the crystal, which would leave some residual entropy not included in the experimental value, it seemed best to retain the good accord with the equilibrium.

After the present calculations were completed, the paper by Aston, Szasz, Woolley, and Brickwedde [22] was published which includes calculations for 1-butene and reports values for the specific heat of the gas. The present authors cannot agree with the assertion of Aston et al. [22] that "the Raman and infrared spectra indicate essentially only one form," because their assignment leaves three Raman lines having frequencies below $600 \mathrm{~cm}^{-1}$ unexplained.

The values of specific heat for gaseous 1-butene are reported in reference [22] as unpublished data of Scott and Wacker with no details being given. Hence, although the present calculations yield values of heat capacity which are higher than the values of Scott and Wacker by about $0.7 \mathrm{cal} / \mathrm{deg}$ mole, it does not seem justified to make extensive revisions until additional experimental data become available.

The use of the exact moment of inertia for skeletal internal rotation calculated by the recently developed methods [21], $18.2 \times 10^{-40} \mathrm{~g} \mathrm{~cm}^{2}$, would have the effect of leading to a potential barrier of $2,240 \mathrm{cal} / \mathrm{mole}$ for the skeletal motion and a heat capacity about $0.05 \mathrm{cal} / \mathrm{deg}$ mole lower in the range of $300^{\circ}$ to $400^{\circ} \mathrm{K}$. Other changes could easily be justified in the vibrational assignment to obtain agreement with the experimental gaseous specific heat values. However, these changes would make slightly greater the difference between observed and calculated values of the entropy. 


\section{Results}

Tables 1 to 5 present values for the freeenergy function, the heat-content function, the entropy, the heat content, and the heat capacity, to $1,500^{\circ} \mathrm{K}$, for the six compounds considered in this report.

Table 6 contains a comparison of the calculated values with the available calorimetric data on heat capacity and entropy. The agreement is seen to be best for ethylene, in which case the spectroscopic data are of considerably higher quality than for the higher olefins. Ethylene lacks, in addition, the complication of internal rotation. For propylene and trans-2-butene the agreement is good. There is a somewhat larger discrepancy in the case of isobutene. The calculated values of the heat capacity in these three cases increase a little too rapidly with temperature.

The unusually complicated nature of the restricting potential in cis-2-butene probably accounts for the relatively less satisfactory agreement in that case. It is planned to perform in the future a more detailed study of the problem regarding the cis-2-butene molecule.

TABLE 1.-Values ${ }^{2}$ of the heat-content function, $\left(H^{\circ}-H_{0}^{\circ}\right) / T$, for the six monoolefins, $\mathrm{C}_{2}$ to $\mathrm{C}_{4}$, for the ideal gaseous state, to $1,500^{\circ} \mathrm{K}$

\begin{tabular}{|c|c|c|c|c|c|c|c|c|c|c|c|c|c|c|c|c|}
\hline \multirow{3}{*}{ Compound (gas) } & \multirow{3}{*}{$\begin{array}{l}\text { For- } \\
\text { mula }\end{array}$} & \multicolumn{15}{|c|}{ Temperature ${ }^{\mathrm{a}}$ in ${ }^{\circ} \mathrm{K}$} \\
\hline & & 0 & 298.16 & 300 & 400 & 500 & 600 & 700 & 800 & 900 & 1,000 & 1,100 & 1,200 & 1,300 & 1,400 & 1,500 \\
\hline & & \multicolumn{15}{|c|}{ Heat Content Function, $\mathrm{b}\left(\mathrm{H}^{\circ}-H_{0}^{\circ}\right) / T$, in cal/deg mole } \\
\hline Ethene (ethylene) & $\mathrm{C}_{2} \mathrm{H}_{4}$ & 0 & 8. 47 & 8. 48 & 9. 28 & 10.23 & 11.22 & 12.18 & 13.10 & 13.96 & 14. 76 & 15. 52 & 16. 22 & 16.88 & 17.50 & 18.07 \\
\hline Propene (propylene) & $\mathrm{C}_{3} \mathrm{H}_{6}$ & 0 & 10.86 & 10.88 & 12. 48 & 14.15 & 15.82 & 17.42 & 18.94 & 20.36 & 21.69 & 22.92 & 24.07 & 25.13 & 26.12 & 27. \\
\hline 1-Butene ... & $\mathrm{C}_{4} \mathrm{H}_{8}$ & 0 & 14.17 & 14. 21 & 16. 72 & 19. 26 & 21.69 & 23.96 & 26.07 & 28.02 & 29.83 & 31.51 & 33.06 & 34.49 & 35.82 & 37.06 \\
\hline cis-2-Butene & $\mathrm{C}_{4} \mathrm{H}_{8}$ & 0 & 13.23 & 13. 27 & 15.36 & 17.68 & 20.01 & 22.26 & 24.39 & 26.38 & 28.23 & 29.96 & 31.57 & 33.06 & 34.45 & 35.74 \\
\hline $\operatorname{trans-2-Butene}$ & $\mathrm{C}_{4} \mathrm{H}_{8}$ & 0 & 14.05 & 14. 10 & 16. 46 & 18.84 & 21.16 & 23.37 & 25.43 & 27.38 & 29.19 & 30.87 & 32.43 & 33.88 & 35.22 & 36. \\
\hline 2-Methylpropene (isobutene) & $\mathrm{C}_{4} \mathrm{H}_{8}$ & 0 & 13.69 & 13.74 & 16.30 & 18.83 & 21.25 & 23.50 & 25.62 & 27.56 & 29.37 & 31.06 & 32.63 & 34.08 & 35.42 & 36.67 \\
\hline
\end{tabular}

a Interpolation to other temperatures in the interval $298.16^{\circ}$ to $1,500^{\circ} \mathrm{K}$ may be made by appropriate graphical or analytical methods. For temperatures between $200^{\circ}$ and $298.16^{\circ} \mathrm{K}$, values may be estimated by extrapolating the values for $300^{\circ}, 400^{\circ}, 500^{\circ}$ and $600^{\circ} \mathrm{K}$. The values in this table are given to more significant figures than are warranted by the absolute accuracy of the individual values in order to retain the internal consistency of the several thermodynamic functions of a single substance, and also to retain the significance of the increments with temperature of a given thermodynamic function.

b The heat-content function, $\left(H^{\circ}-H_{0}^{\circ}\right) / T$, is the heat content at the given temperature less the heat content at $\mathrm{O}^{\circ} \mathrm{K}$, divided by the absolute temperature $\left({ }^{\circ} \mathrm{K}\right)$ of the given hydrocarbon in the thermodynamic standard gaseous state of unit fugacity (1 atmosphere).

TABLE 2.-Values a of the free-energy function, $\left(F^{\circ}-H_{0}^{\circ}\right) / T$, for the six monoolefins, $C_{2}$ to $\mathrm{C}_{4}$, for the ideal gaseous state to $1,500^{\circ} \mathrm{K}$

\begin{tabular}{|c|c|c|c|c|c|c|c|c|c|c|c|c|c|c|c|c|}
\hline \multirow{3}{*}{ Compound (gas) } & \multirow{3}{*}{$\begin{array}{l}\text { For- } \\
\text { mula }\end{array}$} & \multicolumn{15}{|c|}{ Temperature $\mathrm{s}$ in ${ }^{\circ} \mathrm{K}$} \\
\hline & & 0 & 298.16 & 300 & 400 & 500 & 600 & 700 & 800 & 900 & 1,000 & 1,100 & 1,200 & 1,300 & 1,400 & 1,500 \\
\hline & & \multicolumn{15}{|c|}{ Free-energy function, $\mathrm{b}\left(F^{\circ}-H_{0}^{\circ}\right) / T$, in cal/deg mole } \\
\hline Ethene (ethylene). & $\mathrm{C}_{2} \mathrm{H}_{4}$ & 0 & -43.98 & -44.03 & -46.61 & -48.74 & -50.70 & -52.50 & -54.19 & -55.78 & -57.29 & -58.74 & -60.12 & -61.44 & -62.71 & -63.94 \\
\hline Propene (propylene) & $\mathrm{C}_{3} \mathrm{H}_{6}$ & 0 & -52.95 & -53.02 & -56.39 & -59.32 & -62.05 & -64.61 & -67.04 & -69.36 & -71.57 & -73.69 & -75.73 & -77.70 & -79.60 & -81.43 \\
\hline 1-Butene & $\mathrm{C}_{4} \mathrm{H}_{8}$ & 0 & -59.32 & -59.41 & -63.87 & -67.84 & -71.56 & -75.08 & -78.42 & -81.61 & -84.66 & -87.58 & -90.39 & -93.09 & -95.70 & -98.21 \\
\hline cis-2-Butene & $\mathrm{C}_{4} \mathrm{H}_{8}$ & 0 & -58.67 & -58.75 & -62.89 & -66.51 & -69.94 & -73.19 & -76.30 & -79.29 & -82.17 & -84.95 & -87.62 & -90.20 & -92.70 & -95.12 \\
\hline trans-2-Butene.... & $\mathrm{C}_{4} \mathrm{H}_{8}$ & 0 & -56.80 & -56.89 & -61.31 & -65.19 & -68.84 & -72.27 & -75.53 & -78.64 & -81.62 & -84.47 & -87.22 & -89.87 & -92.44 & -94.91 \\
\hline 2-Methylpropene (isobutene). & $\mathrm{C}_{4} \mathrm{H}_{8}$ & 0 & -56.47 & -56.56 & -60.90 & -64.77 & -68.42 & -71.88 & -75.15 & -78.29 & -81.29 & -84.17 & -86.94 & -89.60 & -92.17 & -94.66 \\
\hline
\end{tabular}

s See footnote "a" of table 1 .

b The free-energy function, $\left(F^{\circ}-H_{0}^{\circ}\right) / T$, is the free energy at the given temperature less the heat content at $0^{\circ} \mathrm{K}$, divided by the absolute temperature $\left({ }^{\circ} \mathrm{K}\right)$, of the given hydrocarbon in the thermodynamic standard gaseous state of unit fugacity (1 atmosphere). 
TABLE 3.-Values ${ }^{a}$ of the entropy, $S^{\circ}$, for the six monoolefins, $\mathrm{C}_{2}$ to $\mathrm{C}_{\mathbf{s}}$, for the ideal gaseous state, to $1,500^{\circ} \mathrm{K}$

\begin{tabular}{|c|c|c|c|c|c|c|c|c|c|c|c|c|c|c|c|c|}
\hline \multirow[b]{2}{*}{ Compound (gas) } & \multirow[b]{2}{*}{$\begin{array}{l}\text { For- } \\
\text { mula }\end{array}$} & \multicolumn{15}{|c|}{ Temperature $\mathrm{s}$ in ${ }^{\circ} \mathrm{K}$} \\
\hline & & 0 & 298.16 & 300 & 400 & 500 & 600 & 700 & 800 & 900 & 1,000 & 1,100 & 1,200 & 1,300 & 1,400 & 1,500 \\
\hline Ethene (ethylene)... & $\mathrm{C}_{2} \mathrm{H}_{4}$ & 0 & 52.45 & 52.51 & 55.89 & 58.98 & 61.92 & 64.68 & 67.28 & 69.74 & 72.06 & 74. 26 & 76.34 & 78.32 & 80.21 & 82.01 \\
\hline Propene (propylene). & $\mathrm{C}_{3} \mathrm{H}_{0}$ & 0 & 63.80 & 63.90 & 68.86 & 73. 47 & 77.87 & 82.04 & 85.98 & 89.72 & 93. 26 & 96.61 & 99.80 & 102.84 & 105.98 & 108.48 \\
\hline trans-2-Butene & $\mathrm{C}_{4} \mathrm{H}_{8}$ & 0 & $\begin{array}{l}0.86 \\
\end{array}$ & 70.98 & 77.76 & 84.04 & 90.00 & 95.64 & 100.97 & $\mid 106.02$ & 110.81 & 115. 34 & 119.65 & 123.75 & 127.66 & 131. 38 \\
\hline 2-Methylpropene (isobutene) ... & $\mathrm{C}_{4} \mathrm{H}_{8}$ & 0 & \begin{tabular}{|l|l|}
0 & 70.17 \\
\end{tabular} & 70.30 & 77.21 & 83.60 & 89.67 & 95.38 & 100.77 & 105.85 & 110.66 & 115.23 & 119.56 & 123.68 & 127.59 & 131. 33 \\
\hline
\end{tabular}

- See footnote "a" of table 1.

b $S^{\circ}$ is the entropy (exclusive of nuclear spin) of the given hydrocarbon in the thermodynamic standard gaseous state of unit fugacity (1 atmosphere) at the temperature indicated.

TABLE 4.-Values ${ }^{\mathrm{a}}$ of the heat content, $\left(\mathrm{H}^{\circ}-\mathrm{H}_{0}^{\circ}\right)$, for the six monoolefins, $\mathrm{C}_{2}$ to $\mathrm{C}_{4}$, for the ideal gaseous state, to $1,500^{\circ} \mathrm{K}$

\begin{tabular}{|c|c|c|c|c|c|c|c|c|c|c|c|c|c|c|c|c|}
\hline Compound (gas) & $\begin{array}{l}\text { For- } \\
\text { mula }\end{array}$ & 0 & 298.16 & 300 & 400 & 500 & 600 & 700 & 800 & 900 & 1,000 & 1,100 & 1,200 & 1,300 & 1,400 & 1,500 \\
\hline Ethene (ethylene) & $\mathrm{C}_{2} \mathrm{H}_{4}$ & 0 & 2525 & 2544 & 3711 & 5117 & 6732 & 8527 & 10480 & 12560 & 14760 & 17070 & 19470 & 21950 & 24490 & 27100 \\
\hline Propene (propylene) & $\mathrm{C}_{3} \mathrm{H}_{0}$ & $\mathbf{0}$ & 3237 & 3265 & 4990 & 7076 & 9492 & 12200 & 15150 & 18320 & 21690 & 25210 & 28880 & 32670 & 36570 & 40570 \\
\hline trans-2-Butene & $\mathrm{C}_{4} \mathrm{H}_{8}$ & 0 & 4190 & 4228 & 6582 & 9422 & 12690 & 16360 & 20350 & 24640 & 29190 & 33960 & 38920 & 44040 & 49310 & 54710 \\
\hline 2-Methylpropene (isobutene) & $\mathrm{C}_{4} \mathrm{H}_{8}$ & 0 & 4082 & 4121 & 6522 & 9414 & 12750 & 16450 & 20490 & 24800 & 29370 & 34170 & 39150 & 44300 & 49590 & 55000 \\
\hline
\end{tabular}

s See footnote " $a$ " of table 1 .

b $\left(H^{\circ}-H_{0}^{\circ}\right)$ is the heat content at the given temperature less the heat content at $0^{\circ} \mathrm{K}$ of the given hydrocarbon in the thermodynamic standard gaseous state of unit fugacity (1 atmosphere).

TABLE 5.-Values of the heat capacity, $C_{p}^{\circ}$, for the six monoolefins, $\mathrm{C}_{2}$ to $\mathrm{C}_{4}$, for the ideal gaseous state, to $1,500^{\circ} \mathrm{K}$

\begin{tabular}{|c|c|c|c|c|c|c|c|c|c|c|c|c|c|c|c|c|}
\hline \multirow{3}{*}{ Compound (gas) } & \multirow{3}{*}{$\begin{array}{l}\text { For- } \\
\text { mula }\end{array}$} & \multicolumn{15}{|c|}{ Temperature in ${ }^{\circ} \mathrm{K}$} \\
\hline & & 0 & 298.16 & 300 & 400 & 500 & 600 & 700 & 800 & 900 & 1,000 & 1,100 & 1,200 & 1,300 & 1,400 & 1,500 \\
\hline & & \multicolumn{15}{|c|}{ Heat capacity, b $C_{p}^{\circ}$, in cal/deg mole } \\
\hline Ethene (ethylene)... & $\mathrm{C}_{2} \mathrm{H}_{4}$ & 0 & 10.41 & 10.45 & 12.90 & 15.16 & 17.10 & 18. 76 & 20.20 & 21.46 & 22.57 & 23.54 & 24. 39 & 25.14 & 25.79 & 26. 36 \\
\hline Propene (propylene) ... & $\mathrm{C}_{3} \mathrm{H}_{6}$ & 0 & 15.27 & 15.34 & 19.10 & 22.62 & 25.70 & 28. 37 & 30.68 & 32.70 & 34.46 & 35.99 & 37.32 & 38.49 & 39.51 & 40.39 \\
\hline 1-Butene & $\mathrm{C}_{4} \mathrm{H}_{8}$ & 0 & 21.35 & 21.45 & 26.94 & 31.75 & 35.82 & 39.31 & 42.33 & 44.95 & 47.24 & 49.23 & 50.96 & 52.47 & 53. 79 & 54.93 \\
\hline cis-2-Butene & $\mathrm{C}_{4} \mathrm{H}_{8}$ & 0 & 18.86 & 18.96 & 24.33 & 29.39 & 33.80 & 37.60 & 40.87 & 43.70 & 46.15 & 48. 28 & 50.13 & 51.74 & 53.13 & 54.35 \\
\hline trans-2-Butene & $\mathrm{C}_{4} \mathrm{H}_{8}$ & 0 & 20.99 & 21.08 & 26.02 & 30.68 & 34.80 & 38.38 & 41.50 & 44. 20 & 46.58 & 48.65 & 50.44 & 52.00 & 53.36 & 54.55 \\
\hline 2-Methylpropene (isobutene) & $\mathrm{C}_{4} \mathrm{H}_{8}$ & 0 & 21.30 & 21. 39 & 26.57 & 31.24 & 35.30 & 38.81 & 41.86 & 44.53 & 46.85 & 48.88 & 50.63 & 52.17 & 53.51 & 54.68 \\
\hline
\end{tabular}

s See footnote "a" of table 1.

b $C_{p}^{\circ}$ is the heat capacity at constant pressure of the given hydrocarbon in the thermodynamic standard gaseous state of unit fugacity (1 atmosphere) at the temperature indicated. 
TABLE 6.-Comparison of experimental and calculated values of entropy and gaseous heat capacity

\begin{tabular}{|c|c|c|c|c|}
\hline \multirow{2}{*}{ Temperature $\left({ }^{\circ} \mathbf{K}\right)$} & \multicolumn{2}{|c|}{$\begin{array}{l}\text { Heat capacity, } C: \\
\text { (cal/deg mole) }\end{array}$} & \multicolumn{2}{|c|}{$\begin{array}{l}\text { Entropy, } S^{\circ} \\
\text { (cal/deg mole) }\end{array}$} \\
\hline & Calculated & $\begin{array}{l}\text { Experi- } \\
\text { mental }\end{array}$ & Calculated & $\begin{array}{l}\text { Experi- } \\
\text { mental }\end{array}$ \\
\hline
\end{tabular}

\begin{tabular}{|c|c|c|c|c|}
\hline \multicolumn{5}{|c|}{ ETHYLENE } \\
\hline $169.40 \ldots$ & & $-5-2-2$ & 47.35 & 47. $36[19]$ \\
\hline 270.7 & 9. 77 & $9.74[20]$ & - & $-\cdots$ \\
\hline 300.0 & 10.45 & 10.39 [20] & $\ldots$ & $-\cdots$ \\
\hline $320.7 \ldots$ & 10.96 & $10.99[20]$ & $\ldots$ & -. \\
\hline
\end{tabular}

\begin{tabular}{c} 
PROPYLENE \\
\hline
\end{tabular}

\begin{tabular}{|c|c|c|c|c|}
\hline \multicolumn{5}{|c|}{ cis-2-BUTENE } \\
\hline 245.00 & & & 68.46 & $68.58[7]$ \\
\hline 280.00 & $\ldots$ & $\ldots$ & 70.74 & 70.87 [7] \\
\hline 298.16 & 18.86 & $19.14[7,8]$ & 71.90 & $72.02[7]$ \\
\hline
\end{tabular}

TABLE 6.-Comparison of experimental and calculated values of entropy and gaseous heat capacity-Continued

\begin{tabular}{|c|c|c|c|c|}
\hline \multirow{2}{*}{ Temperature $\left({ }^{\circ} K\right)$} & \multicolumn{2}{|c|}{$\begin{array}{l}\text { Heat capacity, } C_{p} \\
\text { (cal/deg mole) }\end{array}$} & \multicolumn{2}{|c|}{$\begin{array}{l}\text { Entropy, } S^{\circ} \\
\text { (cal/deg mole) }\end{array}$} \\
\hline & Calculated & $\begin{array}{l}\text { Experi- } \\
\text { mental }\end{array}$ & Calculated & $\begin{array}{l}\text { Experi- } \\
\text { mental }\end{array}$ \\
\hline
\end{tabular}

\begin{tabular}{|c|c|c|c|c|}
\hline \multicolumn{5}{|c|}{ cis-2-BUTENE-continued } \\
\hline 332.85 & 20.74 & $20.96[7,8]$ & 1. & - \\
\hline $371.24 \ldots \ldots$ & 22.80 & $22.95[7,8]$ & - & (n) \\
\hline
\end{tabular}

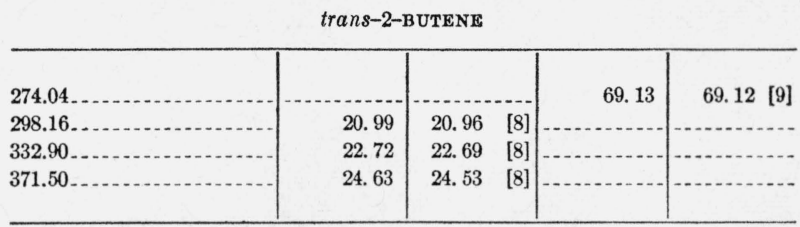

ISOBUTENE

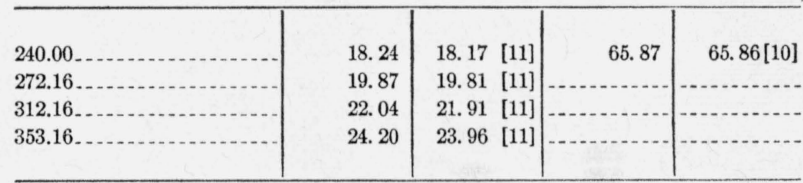

\section{References}

[1] D. D. Wagman, J. E. Kilpatrick, W. J. Taylor, K. S. Pitzer, and F. D. Rossini, J. Research NBS 34, 143 (1945) RP1634.

[2] K. S. Pitzer and W. D. Gwinn, J. Chem. Phys. 10, 428 (1942).

[3] W. S. Gallaway and E. F. Barker, J. Chem. Phys. 10, 88 (1942).

[4] J. E. Kilpatrick and K. S. Pitzer, J. Research NBS 37, (1946). (Publication pending.)

[5] T. M. Powell and W. F. Giauque, J. Am. Chem. Soc. 61, 2366 (1939).

[6] G. B. Kistiakowsky and W. W. Rice, J. Chem. Phys. 8, 610 (1940).

[7] R. B. Scott, W. J. Ferguson and F. G. Brickwedde, J. Research NBS 33, 1 (1944) RP1592.

[8] G. B. Kistiakowsky and W. W. Rice, J. Chem. Phys. 8, 618 (1940).

[9] L. Guttman and K. S. Pitzer, J. Am. Chem. Soc. 67, 324 (1945).

[10] R. D. Rands, Jr., R. B. Scott, and F. G. Brickwedde, National Bureau of Standards, unpublished data.

[11] R. B. Scott and J. W. Mellors, J. Research NBS 34, 243 (1945) RP1640.
[12] K. S. Pitzer, J. Chem. Phys. 12, 310 (1944).

[13] K. W. F. Kohlraush and W. Stockmair, Z. Phys. Chem. B29, 296 (1935).

[14] H. H. Voge and N. C. May, J. Am. Chem. Soc. 68, 550 (1946).

[15] F. E. Frey and W. F. Huppke, Ind. Eng. Chem. 25, 54 (1933).

[16] J. Turkevich, J. Chem. Phys. 12, 461 (1944).

[17] J. E. Kilpatrick, E. J. Prosen, K. S. Pitzer and F. D. Rossini, J. Research NBS 36, 559 (1946) RP1722.

[18] J. G. Aston, H. L. Fink, A. B. Bestul, E. L. Pace, and G. J. Szasz, J. Am. Chem. Soc. 68, 52 (1946).

[19] C. J. Egan and J. D. Kemp, J. Am. Chem. Soc. 59, 1264 (1937).

[20] E. J. Burcik, E. H. Eyster and D. M. Yost, J. Chem. Phys. 9, 118 (1941).

[21] K. S. Pitzer, J. Chem. Phys. 14, 239 (1946).

[22] J. G. Aston, G. Szasz, H. W. Woolley, and F. G. Brickwedde, J. Chem. Phys. 14, 67 (1946).

[23] American Petroleum Institute Research Project 44 at the National Bureau of Standards. Table $\alpha$ (parts 1, 2, and 3), Value of constants.

Washington, May 9, 1946. 